\title{
THE CONTRIBUTION OF CREATIVE WRITING ACTIVITY TOWARD STUDENT'S ENGAGEMENT IN POETRY CLASS
}

\author{
Gina Larasaty ${ }^{* 1}$, Ida Yulianawati ${ }^{{ }^{2}}$ \\ Gina_larasaty@Unwir.ac.id ${ }^{* 1}$, Idayulianawati@unwir.ac.id ${ }^{* 2}$ \\ Faculty of Teachers Training and Education Science - English Education Department \\ University of Wiralodra
}

\begin{abstract}
ABSTARCT
Consider the Creative writing is very popular rightnow, the researcher tried to investigated the Students' engagement through Creative writing activities. This study investigated how far the creative writing will engage the students' in learning poetry. The participant of this study was students in fourth semester of English Department in Wiralodra University. Therefore, this qulitative study sets out to investigate the students' engagement in doing Creative writing activities in poetry Class. The findings suggest that Creative writing activities is able to engage students in poetry classroom. Then emotional engagement ( $M=32,63)$ is dominated followed by behavioral engagement ( $M=17.24)$ and cognitive engagement $(M=15,24)$. So it means Emotional engagement from their perspective has more to do with the pleasant and unpleasant emotions students connect to the activity and behavioral engagement focused on their effort but as cognotively not. In other words, they have effort to simply do the work but cannot focused on understanding and mastery. However this result showed that emotional engagement dominated in students engagement in poetry class, cognitive and behavioural still showed the positive engagement in poetry class.
\end{abstract}

Keywords: Creative writing Activity, Students' Engagement, Poetry Class.

\section{INTRODUCTION}

Nowadays, writing is a skill that is very necessary in the digital era. As Graham and Hebert $(2010 ; 3)$ point out, "globalization and technological advances have changed the nature of the workplace [and] reading and writing are now essential skills in most white and blue collar jobs". Recently, one of type in writing widely studied and included in the curriculum is creative writing. Creative writing becomes more popular in teaching foreign language. It comes along with the idea that children should be given more freedom to express their ideas. Therefore, promoting creative writing is one of the important skills that learners must learn because writing can be a bridge for them to have communication in written language. Troyka and Hesse (2005) proves that people who work in any field in a day, they use thirty percent of their time on writing. Writing also helps them in expressing their ideas and feelings in written language. Therefore, they 
need to learn different types of posts from beginner level to make them better produce their written language.

Creative writing is writing that expresses ideas and thoughts in an imaginative way. Harmer (2001) stated that," the term of creative writing suggests imaginative tasks such as writing poetry, stories, and plays." in the view of teaching, Gaffield-Vile as cited in Harmer (2001) commented that creative writing as, "Self-discovery, and self- discovery promotes effective learning." Therefore, the term of creative writing can help teachers to engage students' in writing since the students will try to produce their writing with appropriate language if the teachers create the imaginative tasks. Harmer (2001) added that, "While students are writing a simple poem about someone they care about, or while they are trying to construct a narrative or tell stories of their childhood, for example, they are tapping into their own experiences. This provides powerful motivation to find the right words to express such experience."

Teaching creative writing is not easy, because it is a challenging for the teachers how to get students engaged in writing activities, particularly creative writing. Engagement is a key factor in succession of learning Process. When students are engaged in the learning process, they are able to gain and develop an interest in acquiring knowledge. According to Chen and Looi (2010), a key stimulus of learning efficacy for students in the classroom is active participation and engagement in the learning process.

In other words creative writing has an important role for teachers because it can help teachers to engage students' in the learning process. In this case, the researcher will investigate Students' Perception and Engagement in Creative Writing.

\subsection{Background of Study}

Nowdays, writing is a skill that is very necessary in the digital era. As Graham and Hebert $(2010 ; 3)$ point out, "globalization and technological

\subsection{Formulation of the problem}

Relate to the problems above, the formulation of the problems are:

1. What extent, does creative writing contribute to students' engagement ?

\subsection{Purpose of the study}

1. To investigate students engagement in creative writing activity. 


\subsection{Significance of the study}

Based on the purpose of the study above, the writer hopes it would be valuable information for the teaching English as Foreign Language. The significance of the study can be explained as follows:

1. To give contribution for the teaching English as Foreign Language. Especially for English Department Students in Wiralodra University.

2. To give Students experience a different genre of writing and help them to explore creative writing in poetry class.

3. To know how far creative writing give the contribution to the students' engagement in EFL Classroom.

\section{LITERATURE REVIEW}

\section{The Concept of Creative Writing.}

According to Harper, Talking about " Creative Writing " is talking about two things, they are the activities of Creative Writing and the finished works that emerge from the activities of Creative Writing. However, most often the term 'Creative Writing' is used to refer to the activities we engage in. The results of these activities, alternatively, are most often referred to by their specific 'art factual' names - for example, the 'poem', 'script', 'story' or 'novel' that emerges from the acts and actions of Creative Writing. (2010 : 2). Then, Maley (2012) considers creative writing as an aesthetically motivated, highly disciplined and a personal activity that deals less in facts than in the imaginative representation of emotions, events, characters and experiences. Another definition of creative writing comes from Ken Hyland (2002) who argues that — we can see [creative writing as] any writing, fiction or non-fiction that occurs outside of everyday professional, journalistic, academic and technical forms of writing (p.15). However, Hyland (2002) also points out that contrary to academic writing which is focused on -rhetorical conventions and discourse expectations of disciplinary communities. (p. 229), the main focus of creative writing is on self-expression.

\section{Creative Writing in Poetry Class}

Nowadays, creative writing has become an independent academic discipline (Hyland, 2002, p. 229), especially at the universities in the United States. Students usually enroll to particular creative writing courses, choose between fiction, poetry, screenwriting or playwriting and further develop their writing and editing skills in the particular area (Hyland, 2002, p. 229).

Researchers have suggested that writing poem is one way to create the creativity. (McGovern \& Hogshead, 1990; Cubukcu, 2010; Lazar, 1996; McKay, 1982).. As Maher suggests $(1986,328)$, 'writing poetry, which involves the full personality of the individual, is first and foremost, a 'playful' activity'. Once 


\section{${\text { Gina } \text { Larasaty }^{*}{ }^{1} \text {, Ida Yulianawati }}^{* 2}$ \\ THE CONTRIBUTION OF CREATIVE WRITING ACTIVITY TOWARD \\ STUDENT'S ENGAGEMENT IN POETRY CLASS}

students explore poetic language, they can gain useful ideas for creative writing. In this respect, writing poetry can be a significant stimulation for students' creativity. Poems also present interesting themes and meaningful language, thereby increase emotional awareness in the learners, and motivating learners not only emotionally but also cognitively to communicate creatively in L2 (Lazar, 1996). In poetry we learn things that are universal that involves emotions, feelings. Through poetry as well as readers get inspired ideas of important ideas, can even produce poetry by utilizing their experience. Each student can respond to poetry differently. Poetry provides a foundation or stimulus, and serves as a good model for creative writing. In Line with Maher (1986) writing poetry involves the full personality of the individual, and is first and foremost, a 'playful' activity. By providing emotional response, 'learners become more personally involved in the process of language learning and can begin to own the language they learn more fully' (Lazar 1996, 773). Once students explore the poetic language, they can gain useful ideas for creative writing. In this respect, writing poetry can be a significant stimulation for student creativity. As acknowledged by Collie and Slater (1987, 226)' using poetry in the classroom can lead naturally on to free, creative written expression'.

\section{Students Engagement}

Before we discuss the definition of Students' Engagement, we try to understand about engagement. According to Cambridge Dictionary, "Engagement is the fact of being involved with something or the process of encouraging people to be interested in the work of an organization". Engagement is more than involvement or participation - it requires feelings and sense making as well as activity (see Harper and Quaye, 2009a, 5). Acting without feeling engaged is just involvement or even compliance; feeling engaged without acting is dissociation. Although focusing on engagement at a school level, Fredricks, Blumenfeld and Paris (2004, 62-63), drawing on Bloom (1956), usefully identify three dimensions to student engagement, as discussed below :

1). Behavioral engagement

Students who are behaviorally engaged would typically comply with behavioral norms, such as attendance and involvement, and would demonstrate the absence of disruptive or negative behavior.

2).Emotional engagement

Students who engage emotionally would experience affective reactions such as interest, enjoyment, or a sense of belonging.

3). Cognitive engagement

Cognitively engaged students would be invested in their learning, would seek to go beyond the requirements, and would relish challenge.

We propose that each of these dimensions can have both a 'positive' and a 'negative' pole, each of which represents a form of engagement, separated by a 
gulf of non-engagement (withdrawal, or apathy). (The terms 'positive' and 'negative' are used here not to denote value judgment, but rather to reflect the attitude implied in much of the literature that compliance with expectations and norms indicates internalization and approval, and is thus seen to be productive, whereas behavior that challenges, confronts or rejects can be disruptive, delaying or obstructive, thus seen to be counterproductive. This is not to deny that, for individual academics, evidence of critical engagement among their students is viewed as a positive indicator of success.) Thus, one can engage either positively or negatively along the behavioral, emotional or cognitive dimensions. This is illustrated in the table below.

Table 1: Examples of positive and negative engagement

\begin{tabular}{|l|l|l|l|}
\hline & $\begin{array}{l}\text { Positive } \\
\text { engagement }\end{array}$ & Non-engagement & $\begin{array}{l}\text { Negative } \\
\text { engagement }\end{array}$ \\
\hline Behavioral & $\begin{array}{l}\text { Attends lectures, } \\
\text { participates with } \\
\text { enthusiasm }\end{array}$ & $\begin{array}{l}\text { Skips lectures } \\
\text { without excuse }\end{array}$ & $\begin{array}{l}\text { Boycotts, pickets } \\
\text { or disrupts } \\
\text { lectures }\end{array}$ \\
\hline Emotional & Interest & Boredom & Rejection \\
\hline Cognitive & $\begin{array}{l}\text { Meets or exceeds } \\
\text { assignment } \\
\text { requirement }\end{array}$ & Assignments late, & $\begin{array}{l}\text { Redefines } \\
\text { parameters for } \\
\text { assignments }\end{array}$ \\
\hline
\end{tabular}

Talking about the concept of Students' Engagement. Students' Engagement is defined as "participation in educationally effective practices, both inside and outside the classroom, which leads to a range of measurable outcomes" (Kuh et al., 2007), and as "the extent to which students are engaging in activities that higher education research has shown to be linked with high-quality learning outcomes" (Krause and Coates, 2008, p. 493) Similarly, Hu and Kuh (2001, p. 3) define engagement as "the quality of effort students themselves devote to educationally purposeful activities that contribute directly to desired outcomes". So, in others words Students' Engagement is referred to students' effort in learning process which leads them to the quality their outcomes 


\section{RESEARCH METHODOLOGY}

Qualitative approach with case study design was used in this study. The purpose of qualitative approach is to understand, describe and explain beliefs, behaviors and meaning in context-specific settings (Wu and Volker, 2009). The populations of this research were Students from EFL Classroom that is student taken from the group of students who take the poetry class at Wiralodra University in academic year 2018/2019.

In collecting the data, the researcher used observation checklist as an instrument. It was aimed to find out the Contribution of creative writing toward students' engagement in poetry Class.

There were five meetings done in this research. Each meeting had one hundred minutes. In the first meeting, the students were taught by using acrostic poetry to promote a creative writing. In the second and third meeting they were taught by using limericks. Then the fourth and fifth meeting were taught writing Haiku., After implementing the creative writing activity, students were given an observation sheet to find out to find out how far students engage in poetry classes.

\section{FINDING AND DISCUSSION}

Among students engagement components, ten (10) items measured emotional engagement, five (5) measured behavioral engagement and five items measured cognitive engagement. The result of this study showed that the total high mean were reported for emotional engagement ( $M=36.6)$ and followed by behavioral $(M=17.24)$ and cognitive engagement $(M=15.24)$. (see chart 1.)

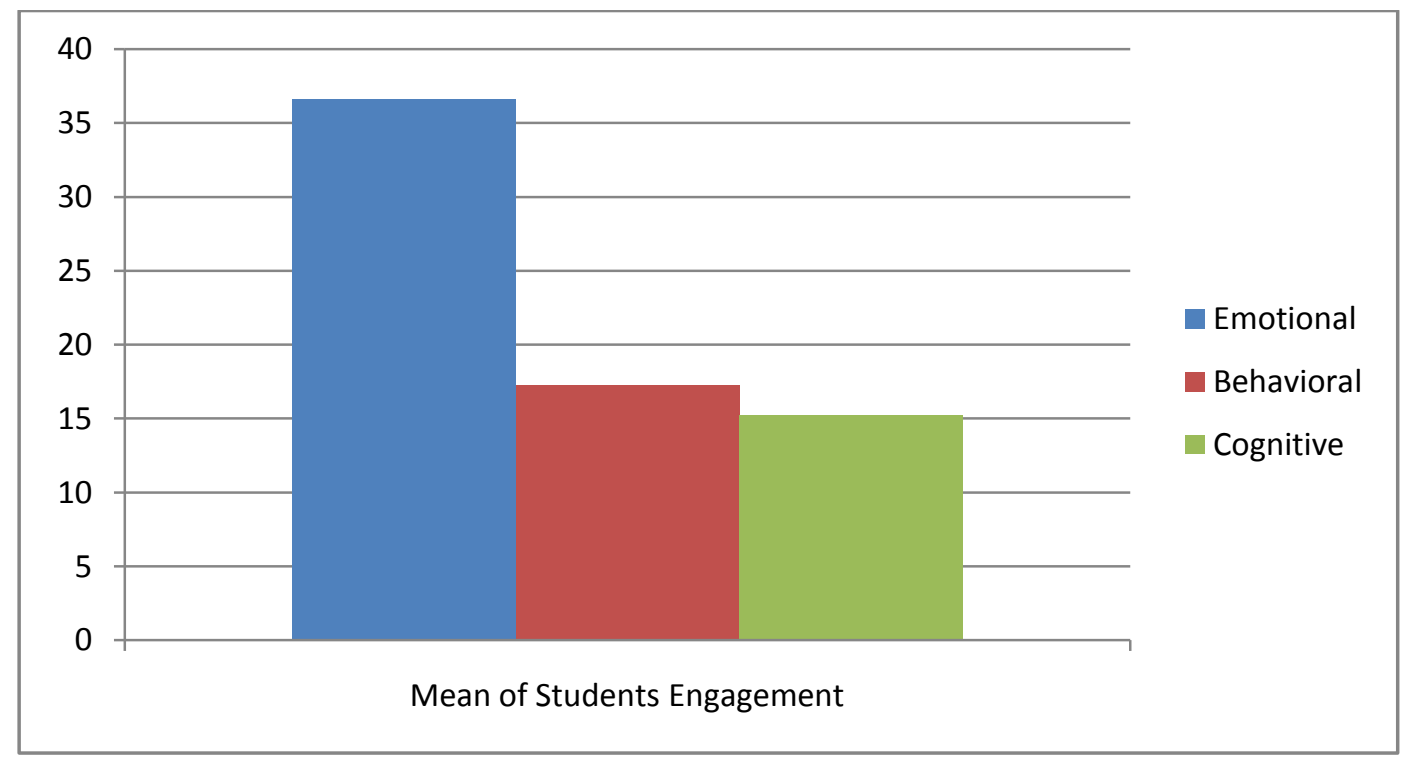

Chart 1. Total Mean Of Students Engagement 
The highest mean score is at the item of emotional engagement (see table 1). Students gave positive response to Creative writing activity. It can be seen that Majority students think that they like Creative writing activities because it allows me to learn enjoyable ( $M=4,28)$. Students also agreed that they like creative writing because it allows me to learn at my own and freely $(M=4,15)$. Then, some of students felt enjoy ( $M=3,67)$, interesting $(M=3,87)$, and confidence $(3,39)$ in creative writing activity. Only few students are worried about writing performance $(M=2,30)$. Then, they like to receive feedback for writing poetry. $(M=2,39)$. But Some Students still felt anxious in learning poetry without the teacher $(\mathrm{M}=3,17)$

Table 1. Mean for Emotional Engagement

\begin{tabular}{|l|l|l|}
\hline \multicolumn{1}{|c|}{ Items } & $\begin{array}{l}\text { Mean } \\
\text { Score }\end{array}$ & Interpretation \\
\hline 1. I enjoyed the creative writing activity & 3,67 & Medium \\
\hline $\begin{array}{l}\text { 2. The creative writing activities was interesting for } \\
\text { me }\end{array}$ & 3,87 & Medium \\
\hline $\begin{array}{l}\text { 3. I feel confident doing the tasks given during the } \\
\text { poetry classroom. }\end{array}$ & 3,39 & Medium \\
\hline $\begin{array}{l}\text { 4. I like creative writing because it allows me to } \\
\text { learn atmy own and freely }\end{array}$ & 4,15 & Very high \\
\hline $\begin{array}{l}\text { 5. I like Creative writing activities because it allows } \\
\text { me to learn enjoyable }\end{array}$ & 4,28 & Very high \\
\hline 6. Creative writing classroom is boring & 2,02 & low \\
\hline $\begin{array}{l}\text { 7. The Creative writing activities motivates me to } \\
\text { learn poetry }\end{array}$ & 3,39 & Medium \\
\hline $\begin{array}{l}\text { 8. I feel anxious (worried, uneasy, fearful, nervous) } \\
\text { learning poetry without my lecturer. }\end{array}$ & 3,17 & Medium \\
\hline $\begin{array}{l}\text { 9. I like receiving feedback for my poetry writing. } \\
\text { after going through }\end{array}$ & 2,39 & low \\
\hline $\begin{array}{l}\text { Total I worry about my poetry writing performance } \\
\text { 10. }\end{array}$ & 2,30 & low \\
\hline
\end{tabular}


Gina Larasaty $^{* 1}$, Ida Yulianawati ${ }^{* 2}$ THE CONTRIBUTION OF CREATIVE WRITING ACTIVITY TOWARD STUDENT'S ENGAGEMENT IN POETRY CLASS

For behavioral engagement, the majority students responded that they put a lot of effort to learn poetry after learning creative writing activities ( $M=3,97)$ and said that they participate actively during the creative writing activity $(\mathrm{M}=$ 3,97 ) (see table 2). Then another responded showed that they can focus well ( $M=3,56)$ and able to complete the activity effectively in poetry class $(M=3,18)$. But there are still students who have low engagement, they still getting trouble completing the task effectively ( $M=2,56$ ). From the overall mean ( $M=17,92$ ) obtained for behavioral construct, it can be said that Creative writing activity was well-received by the respondents.

Table 2. Mean of Behavioral Engagement

\begin{tabular}{|l|l|l|}
\hline Items & $\begin{array}{l}\text { Mean } \\
\text { Score }\end{array}$ & Interpretation \\
\hline $\begin{array}{l}\text { 11. I can focus well during poetry classroom } \\
\text { poetry classroom }\end{array}$ & 3,56 & Medium \\
\hline $\begin{array}{l}\text { 13. I can complete the activity effectively in poetry } \\
\text { class }\end{array}$ & 2.56 & low \\
\hline $\begin{array}{l}\text { 14. I am able to complete the task using the learning } \\
\text { materials provided }\end{array}$ & 3,18 & medium \\
\hline $\begin{array}{l}\text { 15. I put a lot of effort t o learn poetry after doing } \\
\text { creative writing }\end{array}$ & 3,97 & High \\
\hline Total & 17.24 & \\
\hline
\end{tabular}

Cognitive engagement is a matter of students' will — that is, how students feel about themselves and their work, their skills, and the strategies they employ to master their work (Metallidou \& Viachou, 2007). Then based on the table 3. Some of the still confusion $(3,87)$ and can express clearly their idea $(M=3,4)$. Then most of them still difficult in learning poetry ( $M=3,02)$, discourages in learning poetry $M=2,93$ ). Then, students still got low engagement about " creative writing makes me thinking about what $i$ have to learnt and what $i$ am learning in poetry class. 
Table 3. Mean of Cognitive Engagement

\begin{tabular}{|l|l|l|}
\hline Items & $\begin{array}{l}\text { Mean } \\
\text { Score }\end{array}$ & Interpretation \\
\hline $\begin{array}{l}\text { 16. I experienced confusion in learning poetry } \\
\text { creative writing activities. }\end{array}$ & 3,87 & Medium \\
\hline $\begin{array}{l}\text { 19. I am able to clearly express my ideas and my } \\
\text { feeling in poetry class after learning creative writing } \\
\text { activities }\end{array}$ & 3,4 & Medium \\
\hline $\begin{array}{l}\text { 19. Creative writing makes me think about what I } \\
\text { have learnt and what I am learning in poetry class. }\end{array}$ & 2,02 & Low \\
\hline $\begin{array}{l}\text { 20. Creative writing encourages me to explore more } \\
\text { materials online to complete my task in poetry class }\end{array}$ & 2,93 & Low \\
\hline Total & 15,24 & \\
\hline
\end{tabular}

\section{CONCLUSION}

Based on the findings, it can be concluded that Creative Writing Activities is able to engage students in the poetry class in terms of behavior, emotion and cognitive. However this result showed that emotional engagement dominated and followed by behavioral engagement in poetry class.but the students' cognitive engagement was still low. It related to the previous research that in their study of the ways in which classroom structures affected students' emotional engagement, Skinner and Belmont (1993) defined emotional feelings of interest, happiness, anxiety, and anger during achievement-related activities.. So it means Emotional engagement from their perspective has more to do with the pleasant and unpleasant emotions students connect to the activity and behavioral engagement focused on their effort but as cognitively not. In other words, they have effort to simply do the work but cannot focused on understanding and mastery.

However this result showed that emotional engagement dominated in students engagement in poetry class, cognitive and behavioral still showed the positive engagement in poetry class. So we can assume that creative writing activities can help students in engaged in poetry class. 


\section{ACKNOWLEDGMENT}

This research was supported by the Research Fund provided by Directorate of Research and Community service .Directorate General for Research and Development Ministry of Research, Technology and Higher Education. In accordance with The Research Contract for Fiscal Year 2019. The Research Scheme was "Peneliti Dosen Pemula”.

\section{REFERENCES}

Graham and Hebret (2010). Writing to Read : Evidence How for Writing can Improve Reading. New York. Carneige Coorporation.

Troyka, L, \& Hesee, D. (2005). Simon \& Schuster handbook for writers. New Jersey: Pearson Education

Harmer, J. (2001). The Practice of English Language Teaching. 3rd ed. England: Pearson Education Limited

Chen, W., \& Looi, C. (2011). Active Classroom Participation in a Group Scribbles Primary Science Classroom. British Journal Of Educational Technology, 42(4), 676-686.

Harper, Graeme (2010). On Creative Writing. Mutlilingual Matters. Bristol, Buffalo, Toronto

Maley, A. (2012). Creative writing for students and teachers. Humanizing Language Teaching, 14, 3, 1-18.

Hyland, K. (2002). Teaching and Researching Writing. Harlow: Longman.

McGovern, T. V., \& Hogshead, D. L. (1990). Learning about writing, thinking about teaching. Teaching of Psychology, 17, 5-10.

Maher J. (1986) (ed.). 'Poetry for instructional purposes: Authenticity and aspects of performance' in A Forum Anthology: 1979-83 Washington, D.C.: United States Information Agency: 327-333.

Lazar, G. (1996). 'Exploring literary texts with the language learner' TESOL Quarterly, 30 (4), 773-775.

Collie, J., \& Slater, S. (1987). Literature in the language classroom. Cambridge: $C U P$ 
WEJ, Vol 3 No 2 September 2019

Fredricks, J.A., Blumenfeld, P.C. and Paris, A.H. (2004) School Engagement: Potential of the Concept, State of the Evidence. Review of Educational Research. 74 (1), pp. 59-109

Krause, K. and Coates, H. (2008) Students' Engagement in First-Year University. Assessment and Evaluation in Higher Education. 33 (5), pp. 493-505

Kuh, G.D. (2007) How to Help Students Achieve. Chronicle of Higher Education. 53 (41), pp. B12-13

Wu, Hung-Lan \& Volker, Deborah. (2009). The use of theory in qualitative approaches to research: Application in end-of-life studies. Journal of advanced nursing. 65. 2719-32.

Skinner, Ellen \& Belmont, Michael. (1993). Motivation in the classroom:

Reciprocal effect of teacher behavior and student engagement across the school year. Journal of Educational Psychology. 85. 571-581.. 